\title{
Variasi Kosakata Bahasa Ibu dalam Pemerolehan Bahasa Anak Balita di Desa Marga Dauh Puri, Kabupaten Tabanan: Kajian Psikolinguistik
}

\author{
Ni Made Adi Anggaraeni*, I Nyoman Suparwa \\ Program Studi Sastra Indonesia, Fakultas Ilmu Budaya, Universitas Udayana \\ [nimadeadianggaraeni@gmail.com] \\ *Corresponding Author
}

\begin{abstract}
This research is entitled "Vocabulary of Mother Language Variations in Acquiring Toddler Language in Marga Dauh Puri Village, Tabanan Regency: Psycholinguistic Study." The purpose of this study was to find out vocabulary categories, word variations, and factors that influence mastery and acquisition of language variations given his mother to a toddler in Marga Dauh Puri Village, Tabanan Regency. The theory used is the theory of language acquisition proposed by Chaer, the theory of language teaching proposed by Simanjuntak, and the theory of child development proposed by Chaer. To achieve these objectives, several methods and techniques are used. The source of the data for analysis was the family that had a five-year-old child in the Village of Marga Dauh Puri, Tabanan Regency. Furthermore, it was chosen by quota sampling technique. The results of this study are in the form of vocabulary taught by mothers to children including vocabulary categories such as noun categories, verbs, and adjective categories. The use of the dominant language taught is Balinese. Vocabulary variations include repetition and word variations. The dominant vocabulary variation used by mothers is word variation. Factors that influence the mastery and acquisition of vocabulary by children under five, are environmental factors, formal teaching factors, and age factors. The dominant factor influencing the mastery and acquisition of vocabulary by children under five in Marga Dauh Puri Village, Tabanan Regency is an age factor.
\end{abstract}

Keywords: variations in vocabulary, mother tongue, language acquisition

\begin{abstract}
Abstrak
Penelitian ini berjudul "Variasi Kosakata Bahasa Ibu dalam Pemerolehan Bahasa Anak Balita di Desa Marga Dauh Puri, Kabupaten Tabanan: Kajian Psikolinguistik." Tujuan penelitian ini adalah untuk mengetahui kategori kosakata, variasi kata, dan faktor-faktor yang memengaruhi penguasaan dan pemerolehan variasi bahasa yang diberikan ibunya kepada anak balita di Desa Marga Dauh Puri, Kabupaten Tabanan. Teori yang digunakan adalah teori pemerolehan bahasa yang dikemukakan oleh Chaer, teori pengajaran bahasa yang dikemukakan oleh Simanjuntak, dan teori perkembangan anak yang dikemukakan oleh Chaer. Untuk mencapai tujuan tersebut digunakan beberapa metode dan teknik. Sumber data yang dijadikan bahan analisis adalah keluarga yang memiliki anak berusia lima tahun di Desa Marga Dauh Puri, Kabupaten Tabanan. Selanjutnya dipilih
\end{abstract}


dengan teknik sampling kuota. Hasil penelitian ini, yaitu berupa kosakata yang diajarkan ibu kepada anak meliputi kategori kosakata seperti kategori nomina, verba, dan kategori adjektiva. Penggunaan bahasa yang dominan diajarkan adalah bahasa Bali. Variasi kosakata meliputi pengulangan dan variasi kata. Variasi kosakata yang dominan digunakan ibu adalah variasi kata. Faktor yang memengaruhi penguasaandan pemerolehan kosakata oleh anak balita, adalah faktor lingkungan, faktor pengajaran formal, dan faktor usia. Faktor yang dominan memengaruhi penguasaan dan pemerolehan kosakata oleh anak balita di Desa Marga Dauh Puri, Kabupaten Tabanan adalah faktor usia.

Kata kunci: variasi kosakata, bahasa ibu, pemerolehan bahasa

\section{Latar Belakang}

Perkembangan bahasa anak dimulai dari keluarga dan sebagian besar bergantung pada perhatian orang tua dan orang di sekitarnya. Oleh karena itu, pengembangan kemampuan berbahasa di kalangan anak-anak yang dimulai dari lingkungan keluarga akan sangat bermanfaat. Pemerolehan bahasa dikaitkan dengan penguasaan suatu bahasa tanpa disadari secara langsung, yaitu tanpa melalui pendidikan secara formal untuk mempelajarinya. Pemerolehan bahasa anak diikuti oleh perkembangan pralinguistik yang dimulai sejak lahir sampai pada usia satu tahun. Mulai tahun kedua anak dapat menuturkan satu dan dua kata sampai pada umur satu setengah tahun, kemudian gabungan kata dapat diujarkan pada umur satu setengah tahun sampai pada umur dua tahun. Ketika anak berumur dua tahun, anak semakin menyadari bahwa kata-kata yang diujarkan mempunyai makna dalam pemerolehan kata dan dapat membuat pertanyaan-pertanyaan tentang namanama benda yang ada di sekitarnya (Tarigan, 1988:79).

Bahasa ibu merupakan padanan untuk istilah Inggris native language, yaitu satu sistem linguistik yang pertama kali dipelajari secara alamiah oleh anak dari ibu atau keluarga. Bahasa ibu tidak mengacu pada bahasa yang dikuasai dan digunakan oleh seorang ibu (atau biasa disebut bahasa sang ibu), tetapi mengacu pada bahasa yang dipelajari seorang anak dalam keluarga yang mengasuhnya. Ciriciri khusus bahasa sang ibu adalah kalimatnya pendek-pendek, nada suara biasanya tinggi, intonasinya agak berlebihan, laju ujaran agak lambat, banyak redundansi (pengulangan), dan banyak memakai kata sapaan.

Dalam penelitian ini lokasi yang dipilih, yaitu Desa Marga Dauh Puri, Kabupaten Tabanan. Pemilihan lokasi ini karena di Desa Marga Dauh Puri, Kabupaten Tabanan terdapat salah satu objek wisata Puputan Margarana (makam pahlawan) yang terletak di Margarana yang memungkinkan minimnya penggunaan, baik bahasa ibu maupun bahasa Indonesia. Oleh karena itu, pengajaran bahasa ibu kepada anak sangat menarik perhatian peneliti.

\section{Pokok Permasalahan}

Berdasarkan latar belakang yang telah dijabarkan, terdapat tiga masalah yang diteliti. Ketiga permasalahan itu dirumuskan sebagai berikut.

a) Kosakata apa sajakah yang diajarkan ibu kepada anak balita di Desa Marga Dauh Puri, Kabupaten Tabanan?

b) Bagaimanakah variasi kosakata bahasa ibu kepada anak balita di Desa Marga Dauh Puri, Kabupaten Tabanan?

c) Faktor apa sajakah yang memengaruhi penguasaan kosakata dalam pemerolehan bahasa anak balita di Desa Marga Dauh Puri, Kabupaten Tabanan?

\section{Tujuan Penelitian}



berikut.

Adapun tujuan penelitian ini sebagai

a) Untuk mengetahui kosakata yang diajarkan ibu kepada anak balita di Desa Marga Dauh Puri, Kabupaten Tabanan

b) Untuk mengetahui variasi kosakata yang diajarkan ibu kepada anak balita di Desa Marga Dauh Puri, Kabupaten Tabanan

c) Untuk mengetahui faktor yang memengaruhi penguasaan kosakata dalam pemerolehan bahasa anak balita di Desa Marga Dauh Puri, Kabupaten Tabanan.

\section{Metode Penelitian}

Metode dan teknik pengumpulan data yang digunakan dalam penelitian ini adalah metode simak dan dilanjutkan dengan tiga teknik untuk mengumpulkan data, yaitu teknik instrumen (kuesioner), teknik simak libat cakap, dan teknik rekam. Pada tahap analisis data digunakan metode deskriptif kualitatif dan proses penyajian hasil analisis data menggunakan metode informal dan formal.

\section{Hasil dan Pembahasan}

\subsection{Kosakata yang Diajarkan ibu kepada Anak Balita di Desa Marga Dauh Puri, Kabupaten Tabanan}

Berdasarkan analisis data, ditemukan tiga kategori kosakata yang diajarkan ibu kepada anak, yaitu kategori nomina, kategori verba, dan kategori adjektiva. Penggunaan bahasa pada kategori nomina di Banjar Kelaci, yaitu tiga $(30 \%)$ menggunakan bahasa Indonesia, enam $(60 \%)$ menggunakan bahasa Bali, dan satu (10\%) menggunakan bahasa campur, yaitu bahasa Bali dan bahasa Indonesia. Pada kategori verba di Banjar kelaci, yaitu dua (20\%) menggunakan bahasa Indonesia, enam (60\%) menggunakan bahasa Bali, dan dua (20\%) menggunakan bahasa campur, yaitu bahasa Bali dan bahasa Indonesia. Pada kategori adjektiva di Banjar Kelaci, yaitu satu (10\%) menggunakan bahasa Indonesia, sembilan (90\%) menggunakan bahasa Bali, dan untuk kategori adjektiva tidak ada yang menggunakan bahasa campur, yaitu bahasa Bali dan bahasa Indonesia.

Bahasa yang digunakan pada kategori nomina di Banjar Ole, yaitu empat $(26,7 \%)$ menggunakan bahasa Indonesia, tujuh $(46,6 \%)$ menggunakan bahasa Bali, dan empat $(26,7 \%)$ menggunakan bahasa campur, yaitu bahasa Bali dan bahasa Indonesia. Pada kategori verba di Banjar Ole, yaitu empat $(26,7 \%)$ menggunakan bahasa Indonesia, tujuh $(46,6 \%)$ menggunakan bahasa Bali, dan empat $(26,6 \%)$ menggunakan bahasa campur, yaitu bahasa Bali dan bahasa Indonesia. Pada kategori adjektiva di Banjar Ole, yaitu empat $(26,6 \%)$ menggunakan bahasa Indonesia, sepuluh $(66,7 \%)$ menggunakan bahasa Bali, dan untuk kategori adjektiva satu $(6,6 \%)$ yang menggunakan bahasa campur, yaitu bahasa Bali dan bahasa Indonesia.

\subsubsection{Nomina}

Nomina dari segi semantis adalah kata yang mengacu pada manusia, binatang, dan benda (Alwi dkk., 2010:221). Nomina yang diajarkan ibu kepada anak balita ditemukan tiga kategori, yaitu kategori binatang dan tumbuhan, kategori ayah dan ibu, serta kategori organ tubuh. Berikut ini dipaparkan salah satu contoh nomina yang diajarkan ibu kepada anak balita di Desa Marga Dauh Puri, Kabupaten Tabanan.

Data [01] 'anjing'

Jika anak diperkenalkan dengan anjing berbulu hitam, anak akan mengetahui anjing berbulu hitam itu 
disebut anjing. Pada data [01] [cicIn] diperlihatkan bahwa vokal /i/ pada posisi akhir tertutup dilafalkan sebagai /I/ dalam bahasa Bali. Penyebutan kata 'anjing' dalam situasi lingkungan sekolah anak akan menggunakan bahasa Indonesia, saat anak berbicara dengan ibunya, seperti di bawah ini.

Anak : 'Buk, ada anjing sana.'

'Bu, ada anjing di sana.'

Ibu menjawab

$$
\text { Ibu : ' 'Ya, De.' }
$$

Jika berbicara di lingkungan keluarga atau rumah, anak tersebut akan menggunakan bahasa Bali, seperti di bawah ini.

Ibu : 'Mang, cicing be ngamah?'

'Mang, anjing sudah makan?'

'Komang, anjingnya sudah diberi makan?'

Sang anak akan menjawab

anak : 'Ube Me.'

'Sudah Bu.'

\subsubsection{Verba}

Verba yang dikuasai anak usia prasekolah berhubungan dengan aktivitas atau tindakan sehari-hari yang dilakukan anak (Alwi dkk., 2010:222). Kosakata tersebut termasuk kategori verba bentuk dasar. Berikut ini dipaparkan salah satu contoh verba yang diajarkan ibu kepada anak balita di Desa Marga Dauh Puri, Kabupaten Tabanan.

Data [21] 'cium'

Pada data [21] diperlihatkan bahwa kata 'cium' mendapat konsonan /y/ pada posisi tengah dalam bahasa Indonesia. Penyebutan kata 'cium', baik dalam situasi lingkungan sekolah maupun lingkungan keluarga menggunakan bahasa Bali diman, seperti di bawah ini.

Ibu : 'Diman meme, Dek!'

'Cium ibu, Dek!'

'Cium ibu, Kadek!'

Anak pun menjawab

Anak : 'Nggih Me'
'Ya Bu'

\subsubsection{Adjektiva}

Adjektiva yang dikuasai anak usia prasekolah hanya kategori adjektiva dasar (Alwi dkk., 2010:224). Adjektiva bentuk dasar memiliki makna yang mandiri meskipun tidak dibubuhi dengan afiks. Berikut ini dipaparkan salah satu contoh adjektiva yang diajarkan ibu kepada anak balita di Desa Marga Dauh Puri, Kabupaten Tabanan.

Data [41] 'baik'

Pada data [41] diperlihatkan bahwa kata 'baik' mendapat vokal/i/ pada posisi akhir tertutup dilafalkan sebagai /I/ dalam bahasa Indonesia, sedangkan dalam bahasa Bali [luw $v$ ], [bəcIk] mendapat vokal /i/ pada posisi akhir tertutup dilafalkan /I/. Di samping itu, juga memperlihatkan pengucapan suatu bunyi yang disertai embusan keluarnya udara dengan kuat sehingga terdengar bunyi /w/ serta mendapat vokal /u/ pada posisi akhir tertutup dilafalkan $/ \mho /$. Penyebutan kata 'baik' dalam situasi lingkungan sekolah menggunakan bahasa Indonesia, seperti di bawah ini.

Ibu : 'Baik gurunya Gus?'

'Baik gurunya Nak?'

Anak pun menjawab

Anak : 'Baik Bu'

Jika berbicara di lingkungan keluarga atau rumah, anak tersebut menggunakan bahasa Bali, seperti di bawah ini.

Ibu : 'Dek, buku luung?'

'Dek, bukunya bagus?'

'Kadek, bukunya bagus?'

Sang anak akan menjawab

anak : 'Luung Me.'

'Bagus Bu.'

\subsection{Variasi Kosakata Bahasa ibu kepada Anak Balita di Desa Marga Dauh Puri, Kabupaten Tabanan \\ Dalam penelitian ini ditemukan dua jenis variasi kata bahasa ibu dalam}


pemerolehan bahasa anak balita di Desa Marga Dauh Puri, Kabupaten Tabanan, yaitu pengulangan, seperti kategori ajakan, kategori larangan, kategori pronomina, kategori nomina, kategori verba, kategori adjektiva, kategori adverbia, dan kategori numeralia. Variasi kata berupa variasi lafal, variasi afiks, dan pemendekan bunyi. variasi kosakata yang diajarkan ibu kepada anak balita di Desa Marga Dauh Puri, Kabupaten Tabanan ditemukan sebanyak 31 kosakata. Semua kosakata tersebut digolongkan atas 14 kata $(43,75 \%)$ pengulangan dan 18 kata $(56,25 \%)$ variasi kata.

\subsubsection{Pengulangan}

Pengulangan adalah proses pembentukan kata dengan mengulang bentuk dasar, baik secara utuh maupun sebagian, baik dengan variasi fonem maupun tidak (Soedjito, 2009:109). Berikut ini dipaparkan salah satu contoh pengulangan yang diajarkan ibu kepada anak balita di Desa Marga Dauh Puri, Kabupaten Tabanan.

\section{Data [61] 'ayo'}

Pada data [61] di atas terjadi pengulangan kata ajakan. Pengulangan ini terjadi ketika sang ibu memanggil anaknya, baik untuk mengajak keluar maupun melakukan sesuatu, tetapi sang anak belum meresponsnya. Jika pengulangan kata tersebut diucapkan, dengan segera anak melakukan apa yang dikatakan ibunya. Contoh penggulangan kata 'ayo', tampak di bawah ini.

Ibu : 'Ayo-ayo maam dulu!'

'Ayo-ayo makan dulu!'

'Ayo cepat makan dulu!'

\subsubsection{Variasi Kata}

Kosakata yang diajarkan ibu tidak semua dapat diterima dengan baik oleh anak. Baik perbedaan fonem maupun proses terbentuknya kata yang diterima anak tidak menimbulkan makna baru pada sebuah kata yang diajarkan. Berikut ini dipaparkan salah satu contoh variasi kata yang diajarkan ibu kepada anak balita di Desa Marga Dauh Puri, Kabupaten Tabanan.

Data [75] 'bunga' menjadi bungə

Pada data [75] di atas terjadi perubahan fonem /a/ menjadi fonem / $/$ / Kata 'bunga' dalam bahasa Bali menggunakan fonem /a/ pada akhir kata, sedangkan dalam pelafalannya kata 'bunga' dilafalkan dengan fonem / / / Perubahan lafal ini tidak menimbulkan makna baru. Kata bungə memiliki makna tumbuhan.

\subsection{Faktor yang Memengaruhi Penguasaan Kosakata dalam Pemerolehan Bahasa Anak Balita di Desa Marga Dauh Puri, Kabupaten Tabanan}

Berdasarkan analisis data faktorfaktor yang memengaruhi pengajaran kosakata bahasa ibu kepada anak balita di Desa Marga Dauh Puri, Kabupaten Tabanan ditemukan sebanyak tiga faktor dengan 31 sikap anak. Semua faktor tersebut digolongkan atas sembilan (29\%) faktor lingkungan, sembilan (29\%) faktor pengajaran, dan tiga belas $(42 \%)$ faktor usia. Dengan demikian, dapat dikatakan bahwa sebagian besar dipengaruhi oleh faktor usia.

\subsubsection{Faktor Lingkungan}

Faktor lingkungan sangat besar memengaruhi proses pengajaran kosakata bahasa ibu kepada anak balita. Keberhasilan dalam mempelajari bahasa kedua dipengaruhi oleh lingkungan bahasa saat pengajaran bahasa. Lingkungan bahasa meliputi situasi di sekolah, di rumah, percakapan dengan teman-teman, ketika menonton televisi, dalam proses belajar mengajar di dalam kelas, dan sebagainya. Kualitas 
lingkungan bahasa ini merupakan sesuatu yang penting bagi anak untuk memperoleh keberhasilan dalam mempelajari bahasa kedua.

Adapun hal-hal penghambat yang dilakukan anak saat ibu mengajarkan kosakata, seperti nakal atau tidak menurut, sering menentang, dan susah untuk berkomunikasi. Selain tiga perilaku tersebut, faktor yang menyebabkan terjadinya variasi bahasa dalam pengajaran kosakata bahasa ibu yang menggunakan bahasa Indonesia dan bahasa Bali, yaitu faktor eksternal. Faktor eksternal yang diperoleh di lapangan, yaitu berdasarkan situasi berkomunikasi. Pertama berdasarkan situasi, ibu mengajarkan bahasa daerah dalam situasi sehari-hari, sedangkan dalam situasi formal ataupun situasi di luar lingkungan keluarga ibu juga ingin mengajari anak bahasa Indonesia.

\subsubsection{Faktor Pengajaran Formal}

Pengaruh pembelajaran bahasa kedua secara formal di kelas terlihat pada kecepatan dalam menguasai kaidahkaidah dan bentuk-bentuk kebahasaan. Meskipun penguasaan kaidah kebahasaan tidak memengaruhi proses performansinya, penguasaan ini dapat berfungsi untuk memilah kosakata yang diajarkan. Dalam pengajaran kosakata bahasa ibu, anak cenderung melakukan hal-hal yang membuat tidak fokus dalam penerimaan kosakata. Adapun hal yang dilakukan anak saat pengajaran formal berlangsung, seperti kurang tanggap, kurang konsentrasi, dan tidak dapat membedakan kata yang baik dan buruk untuk berkomunikasi.

\subsubsection{Faktor Usia}

Dalam hal kecepatan dan keberhasilan memperoleh bahasa kedua, anak-anak lebih berhasil daripada orang dewasa. Dalam pemerolehan bidang fonologi atau pelafalan, anak-anak lebih berhasil mencapai pelafalan seperti penutur asli. Dalam pemerolehan bidang morfologi dan sintaksis orang dewasa tampaknya maju lebih cepat daripada anak-anak. Oleh sebab itu, anak-anak lebih berhasil daripada orang dewasa, tetapi tidak selalu lebih cepat. Dalam pemerolehan dan penguasaan bahasa ini anak cenderung melakukan hal-hal yang membuat tidak fokus dalam penerimaan kosakata. Adapun hal yang dilakukan anak berusia lima tahun saat pemerolehan kosakata, seperti rasa ingin tahu yang besar, hiperaktif, susah diberi tahu, menangis, dan berbicara kurang jelas.

\section{Simpulan}

Berdasarkan analisis data, dalam pemerolehan variasi kosakata bahasa ibu kepada anak balita di Desa Marga Dauh Puri, Kabupaten Tabanan ditemukan tiga jenis kosakata yang diajarkan ibu kepada anak balita di Desa Marga Dauh Puri, Kabupaten Tabanan, yaitu nomina, verba, dan adjektiva. Dalam pengajaran bahasa ibu terdapat faktor yang memegaruhi penguasaan dan pemerolehan kosakata oleh anak balita di Desa Marga Dauh Puri, Kabupaten Tabanan terdiri atas tiga faktor, yaitu faktor lingkungan, faktor pengajaran, dan faktor usia. Dalam hal ini faktor yang memengaruhi penguasaan dan pemerolehan kosakata oleh anak balita paling banyak disebabkan oleh faktor usia.

\section{Saran}

Variasi kosakata bahasa ibu diharapkan dapat diajarkan sejak dini kepada anak. Pemerolehan bahasa anak merupakan hal penting agar sejak dini anak mengenal jenis kata untuk berkomunikasi, baik kepada teman-teman maupun keluarga. Saat ini sudah banyak orang tua yang merencanakan penggunaan bahasa daerah saat berkomunikasi kepada anaknya. Namun, pengajaran menggunakan bahasa daerah saja sangat disayangkan karena anak lebih dominan mampu berkomunikasi 
dengan bahasa daerah daripada dengan bahasa Indonesia. Oleh karena itu, diharapkan agar orang tua dapat mengajari anaknya dengan bahasa daerah, bahasa Indonesia, dan bahasa asing. Peneliti berharap semoga hasil penelitian ini dapat dijadikan referensi oleh peneliti lain untuk meneliti bahasa ibu dalam pemerolehan bahasa anak dalam tataran lain, seperti semantik, sintaksis, dan pragmatik.

\section{Daftar Pustaka}

Alwi, Hasan dkk. 2010. Tata Bahasa Baku Bahasa Indonesia. Jakarta: Balai Pustaka.

Annisa, Siti Rabiatun Nur. 2016. "Penguasaan Leksikal pada Anak Balita di TK dan PAUD Tunas Kori Dharma: Kajian Psikolinguistik". Skripsi. Jurusan Sastra Indonesia, Fakultas Sastra dan Budaya, Universitas Udayana.

Chaer, Abdul. 2003. Psikolinguistik: Kajian Teoretik. Jakarta: Rineka Cipta.

Herlina. 2016. "Pemerolehan Fonologi Pada Anak Usia Dua Tahun Dua Bulan".Skripsi. Jurusan Pendidikan Anak Usia Dini (PAUD), Fakultas Ilmu Pendidikan, Universitas Negeri Jakarta.

Meilan, Arsanti. 2014. "Pemerolehan Bahasa Anak (Kajian Psikolinguistik). Skripsi. Jurusan Pendidikan Bahasa dan Sastra Indonesia, Fakultas Keguruan dan Ilmu Pendidikan, Universitas Islam Sultan Agung.

Putri, Kunti dkk. 2015. "Pemerolehan Bahasa Indonesia pada Anak Usia Dini di Desa Beraban, Kecamatan Kediri Kabupaten Tabanan". Tesis. Jurusan Pendidikan Bahasa, Program Pascasarjana, Universitas Pendidikan Ganesha.
Simanjuntak, Mangantar. 1987. Pengantar Psikolinguistik Modern. Kuala Lumpur: Dewan Bahasa dan Pustaka Kementerian Pelajaran Malaysia.

Tarigan, Henry Guntur. 1988. Pengajaran Pemerolehan Bahasa. Bandung: Angkasa Bandung. 